\title{
Plant growth-promoting activities of Streptomyces spp. in sorghum and rice
}

\author{
Subramaniam Gopalakrishnan*, Vadlamudi Srinivas, Meesala Sree Vidya and Abhishek Rathore
}

\begin{abstract}
Five strains of Streptomyces (CAl-24, CAl-121, CAl-127, KAl-32 and KAl-90) were earlier reported by us as biological control agents against Fusarium wilt of chickpea caused by Fusarium oxysporum f. sp. ciceri (FOC). In the present study, the Streptomyces were characterized for enzymatic activities, physiological traits and further evaluated in greenhouse and field for their plant growth promotion (PGP) of sorghum and rice. All the Streptomyces produced lipase, $\beta-1-3-g l u c a n a s e$ and chitinase (except CAl-121 and CAl-127), grew in $\mathrm{NaCl}$ concentrations of up to $6 \%$, at pH values between 5 and 13 and temperatures between 20 and $40^{\circ} \mathrm{C}$ and were highly sensitive to Thiram, Benlate, Captan, Benomyl and Radonil at field application level. When the Streptomyces were evaluated in the greenhouse on sorghum all the isolates significantly enhanced all the agronomic traits over the control. In the field, on rice, the Streptomyces significantly enhanced stover yield (up to 25\%; except CAl-24), grain yield (up to 10\%), total dry matter (up to 18\%; except CAl-24) and root length, volume and dry weight (up to 15\%, 36\% and 55\%, respectively, except CAl-24) over the control. In the rhizosphere soil, the Streptomyces significantly enhanced microbial biomass carbon (except CAl-24), nitrogen, dehydrogenase (except CAl-24), total N, available P and organic carbon (up to 41\%, 52\%, $75 \%, 122 \%, 53 \%$ and $13 \%$, respectively) over the control. This study demonstrates that the selected Streptomyces which were antagonistic to FOC also have PGP properties.
\end{abstract}

Keywords: Antagonistic Streptomyces; Plant growth promotion; Field evaluation; Fusarium oxysporum f. sp. ciceri; Sorghum; Rice

\section{Introduction}

Plant growth-promoting (PGP) microbes are rhizosphere associated organisms that colonize the rhizosphere and rhizoplane and improve plant growth when artificially inoculated onto the seeds or into soil. PGP microbes may promote plant growth either by direct stimulation such as iron chelation, phosphate solubilization, nitrogen fixation and phytohormone production or by indirect stimulation such as suppression of plant pathogens and induction of resistance in host plants against pathogens (Basak and Biswas 2009; Hao et al. 2011; Panhwar et al. 2012). The opportunities of PGP microbes include alternating applications of PGP microbes as bio-fungicides with inorganic fungicides to manage fungicide resistance and to reduce the number of fungicide applications per year. PGP microbes also plays an important role in inte-

\footnotetext{
* Correspondence: s.gopalakrishnan@cgiar.org

International Crops Research Institute for the Semi-Arid Tropics (ICRISAT), Patancheru 502 324, Andhra Pradesh, India
}

run-off of unused fertilizers and the environment damage that results (Kloepper 2009; Gopalakrishnan et al. 2013a).

PGP and biological control of plant pathogens has been addressed using actinomycete, bacterial and fungal antagonists. For example, strains of Streptomyces, Bacillus, Pseudomonas and Trichoderma were effective not only in helping plants to mobilize and acquire nutrients but also to control plant pathogens (Postma et al. 2003; Khan et al. 2004; Perner et al. 2006; Borriss et al. Borriss et al. 2011; Gopalakrishnan et al. 2011a, b). Microorganisms with PGP and biocontrol potential were found at high incidence in compost, forest and pasture soils (Torsvik et al. 2002; Tinatin and Nurzat 2006). PGP traits of actinomycetes have been reported on pea (Tokala et al. 2002), bean (Nassar et al. 2003), tomato (El-Tarabily 2008), wheat (Sadeghi et al. 2012) and rice (Gopalakrishnan et al. 2012a).

Five strains of Streptomyces spp. (CAI-24, CAI-121, CAI-127, KAI-32 and KAI-90), isolated from herbal 
vermi-compost, were earlier reported by us as having potential for biocontrol of Fusarium wilt in chickpea, caused by Fusarium oxysporum f. sp. ciceri (FOC; Gopalakrishnan et al. 2011b). Also, the selected Streptomyces strains were reported to produce siderophore, indole acetic acid (IAA; except KAI-90), hydrocyanic acid, cellulase (only KAI-32 and KAI-90) and protease (only for CAI-24 and CAI-127). The objective of this study was to further characterize the five Streptomyces strains for their enzymatic activities (chitinase, lipase and $\beta$-1-3-glucanase), physiological traits (salinity, $\mathrm{pH}$, temperature, fungicide tolerance and antibiotic resistance) and to evaluate for their PGP traits under greenhouse and field conditions in sorghum and rice.

\section{Materials and methods Streptomyces strains}

Five strains of Streptomyces, isolated from herbal vermicompost, CAI-24 (Streptomyces tsusimaensis; NCBI Accession Number: JN400112), CAI-121 (Streptomyces caviscabies; NCBI Accession Number: JN400113), CAI-127 (Streptomyces setonii; NCBI Accession Number: JN400114), KAI32 (Streptomyces africanus; NCBI Accession Number: JN400115) and KAI-90 (Streptomyces spp.; NCBI Accession Number: JN400116), reported earlier by us as potential for biocontrol traits against Fusarium wilt in chickpea (Gopalakrishnan et al. 2011b), were further studied in this investigation.

\section{Evaluation of Streptomyces strains for their enzymatic activities}

Chitinase, lipase and $\beta-1,3-$ glucanase production

Chitinase and lipase production was conducted for all five strains (CAI-24, CAI-121, CAI-127, KAI-32 and KAI-90) of Streptomyces as described by Hirano and Nagao (1988) and Bhattacharya et al. (2009), respectively. The Streptomyces were streaked onto chitin agar (for chitinase) and Tween 80 agar (for lipase) and the Petri dishes were incubated at $28 \pm 2^{\circ} \mathrm{C}$ for five days. At the end of incubation, the Petri dishes were observed for haloes around the colonies, indicating the production of these enzymes. All the treatments were replicated three times and the experiment was conducted three times. Chitinase production was recorded on a $0-5$ rating scale as follows: $0=$ no halo; $1=$ halo of $1-5 \mathrm{~mm} ; 2=$ halo of $6-10 \mathrm{~mm} ; 3=$ halo of $11-15 \mathrm{~mm} ; 4=$ halo of $16-20 \mathrm{~mm}$ and $5=$ halo of $21 \mathrm{~mm}$ and above. Observations for lipase production were recorded on a $0-5$ rating scale as follows: $0=$ no halo; 1 = positive; $2=$ halo of $1-3 \mathrm{~mm} ; 3=$ halo of 4-6 $\mathrm{mm} ; 4=$ halo of $7-10 \mathrm{~mm}$ and $5=$ halo of $11 \mathrm{~mm}$ and above.

$\beta-1,3$-glucanase was measured as per the protocols of Singh et al. (1999). All five Streptomyces strains were cultured individually in Tryptic soy broth, supplemented with $1 \%$ (weight/volume) colloidal chitin, at $28^{\circ} \mathrm{C}$ for four days. At the end of the incubation, the cultures were processed as per Gopalakrishnan et al. (2013b). The development of a dark red color indicated the presence of $\beta-1$, 3 -glucanase. Treatments were replicated three times and the experiment was conducted three times. One unit of $\beta$-1,3-glucanase activity was defined as the amount of enzyme that liberated $1 \mu \mathrm{mol}$ of glucose hour ${ }^{-1}$ under defined conditions.

\section{Evaluation of Streptomyces strains for their physiological traits \\ Salinity, $\mathrm{pH}$ and temperature}

The five Streptomyces were streaked on Bennett's agar with $\mathrm{NaCl}$ concentrations ranging from $0-8 \%$ (at intervals of 2\%) and $\mathrm{pH}$ ranging from 5-13 (at intervals of 2 $\mathrm{pH}$ units); for $\mathrm{pH} 3$, Bennett's broth was used and the intensity of growth was measured at $600 \mathrm{~nm}$ in a spectrophotometer after incubation at $28 \pm 2^{\circ} \mathrm{C}$ for five days. For evaluating the effect of temperature, the five Streptomyces strains were streaked on Bennett's agar and incubated at 20,30 and $40^{\circ} \mathrm{C}$ for five days, but for $50^{\circ} \mathrm{C}$, Bennett's broth was used and the intensity of growth was measured at $600 \mathrm{~nm}$ in a spectrophotometer.

\section{Fungicide tolerance}

Fungicide tolerance studies were conducted for Thiram (dimethylcarbamothioylsulfanyl $N, N$-dimethylcarbamodithioate), Bavistin (carbindozim 50\%; methyl benzimidazol-2ylcarbamate), Benlate (benomyl 50\%; methyl [1-[(butylamino) carbonyl]-1H-benzimidazol-2-yl] carbamate), Captan (captan 50\%; $\mathrm{N}$-trichloromethylthio-4-cyclohexene-1, 2dicarboximide), Benomyl (methyl [1-[(butylamino)carbonyl]-1H-benzimidazol-2-yl]carbamate) and Radonil ( $N$-(2,6-dimethylphenyl)- $N$-(methoxyacetyl) alanine methyl ester) at field application levels of 3000, 2500, 4000, 3000, 3000 and $3000 \mathrm{ppm}$ concentrations, respectively. The required quantities of fungicides were dissolved in sterilized Milli Q water and mixed with Bennett's agar just before pouring into Petri plates. Upon solidification, the five Streptomyces were inoculated and incubated at $28 \pm 2^{\circ} \mathrm{C}$ for five days.

All the physiological traits were replicated three times and the experiment was conducted three times. Responses of the five Streptomyces to salinity, $\mathrm{pH}$, temperature and fungicide tolerance were recorded as follows: $0=$ no growth; 1 = slight growth; $2=$ moderate growth and $3=$ good growth.

\section{Evaluation of Streptomyces strains for their PGP potential under greenhouse conditions on sorghum}

The five Streptomyces strains antagonistic against FOC (CAI-24, CAI-121, CAI-127, KAI-32 and KAI-90) were evaluated in a greenhouse for their PGP potential on 
sorghum. A total of six treatments (five Streptomyces strains + un-inoculated control) were made with six replications. Pot mixture (1000 g) was prepared by mixing red soil, sand and farmyard manure at 3:2:2 and placed in $20 \mathrm{~cm}$ diam plastic pots. Sorghum seeds (variety ICSV 112) were surface sterilized with sodium hypochlorite $(2.5 \%$ for $5 \mathrm{~min})$ and rinsed with sterilized water $(8$ times) before being transferred into the respective test Streptomyces strains $\left(10^{8} \mathrm{cfu} \mathrm{ml}^{-1}\right.$; grown in starch casein broth (SCB) separately) for an hour before being sown in the pots (six seeds/pot but thinned to three after one week). Booster doses of Streptomyces strains $(5 \mathrm{ml}$ per seedling, $10^{8} \mathrm{cfu} \mathrm{ml}^{-1}$ ) were applied at 15, 30 and 45 days after sowing by the soil drench method. Growth parameters including plant height, leaf area, stem and leaf dry weight, root length, root surface area, root volume and root dry weight were determined at day 60 after sowing.

\section{Evaluation of Streptomyces strains for their PGP potential under field conditions on rice}

The field trial was performed in the 2011 Kharif (rainy) season at ICRISAT, Patancheru, Hyderabad, India. The details of the experimental site, soil and the experiment were described previously (Gopalakrishnan et al. 2012a). The experiment was conducted in a randomized complete block design with three replicates and subplot sizes of $10 \times 7.5 \mathrm{~m}$. Rice was grown by the system of rice intensification (SRI) method as described by Uphoff (2003). The five Streptomyces (CAI-24, CAI-121, CAI127, KAI-32 and KAI-90) were grown on SCB at $28^{\circ} \mathrm{C}$ for five days before evaluated for their PGP traits. The control plots contained no Streptomyces. The 11-day-old single seedlings were uprooted from the nursery (laid next to the experimental field), their roots dipped in the respective Streptomyces broth (containing $10^{7} \mathrm{cfu} \mathrm{mL}^{-1}$ ) for $60 \mathrm{~min}$ and transplanted on 4th August 2011 at a spacing of $25 \times 25 \mathrm{~cm}$ (row-to-row and plant-to-plant spacing). Plants were inoculated with respective Streptomyces strains $\left(1500 \mathrm{ml} ; 10^{7} \mathrm{cfu} \mathrm{ml}^{-1}\right)$ once in every two weeks until the flowering stage along with the irrigation water. Irrigation management was performed as recommended for the SRI method (alternate wetting and drying method; Uphoff et al. 2009). Weeding was performed by a Conoweeder at intervals of 15 days after transplanting until the flowering stage. The crop was not sprayed with any chemicals as no serious insect-pests/pathogens were noticed. The recommended dose of N:P:K (120: 60:40 $\mathrm{kg} \mathrm{ha}^{-1}$ ) were applied through compost and farm yard manure. The crop was harvested manually on 23rd November 2011 and observed for plant height, number of tillers, primary and secondary panicle numbers, panicle length, stover yield, grain yield, total dry matter and 1000 seed weight. Root samples were collected from $0-15 \mathrm{~cm}$ and 15-30 $\mathrm{cm}$ soil profile after harvesting and analyzed for root length density (EPSON expression 1640×, Japan), volume and dry weight (dried in an oven at $60^{\circ} \mathrm{C}$ for $72 \mathrm{~h}$ ). Soil samples (from $0-15 \mathrm{~cm}$ soil profile) were collected at harvesting and analyzed for soil chemistry (\% organic carbon, available phosphorous and total nitrogen as per the standardized protocols of Nelson and Sommers (1982); Olsen and Sommers (1982) and Novozamsky et al. (1983), respectively) and biological analysis (dehydrogenase activity, microbial biomass nitrogen and microbial biomass carbon as per Casida (1977), Brooks et al. (1985) and Anderson and Domsch (1989), respectively).

\section{Statistical analysis}

The greenhouse and field experiment data were subjected to ANOVA (GenStat 10.1 version 2007, Lawes Agricultural Trust, Rothamsted Experimental Station) to evaluate the efficiency of the PGP agents. Significance of differences between the treatment means were tested at $P=0.01$ and 0.05 .

\section{Results}

Evaluation of Streptomyces strains for their enzymatic activities and physiological traits

All five Streptomyces strains produced $\beta$-1,3-glucanase and lipase but only three strains (CAI-24, KAI-32 and KAI-90) produced chitinase (Figure 1). All strains were able to grow in $\mathrm{NaCl}$ up to $6 \%$, at $\mathrm{pH}$ values between 5 and 13 and temperatures between 20 and $40^{\circ} \mathrm{C}$. They were highly tolerant to Bavistin but sensitive to Thiram, Benlate, Captan, Benomyl and Radonil at field application levels. A pH of 5 and $10 \% \mathrm{NaCl}$ were discriminatory for the strains, strain CAI-121 showing no growth at $\mathrm{pH}$ 5 while others exhibited medium growth whereas strain CAI-127 showed medium growth at $10 \% \mathrm{NaCl}$ while others exhibited none (Figure 2).

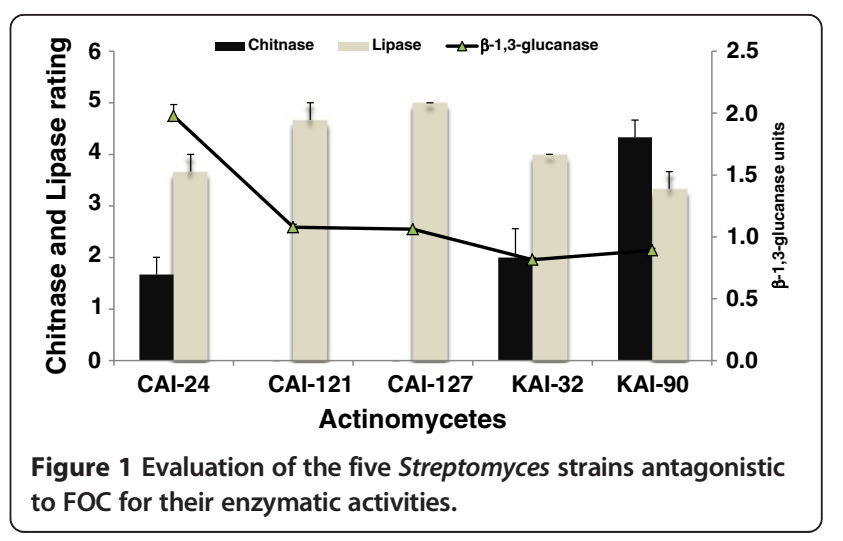



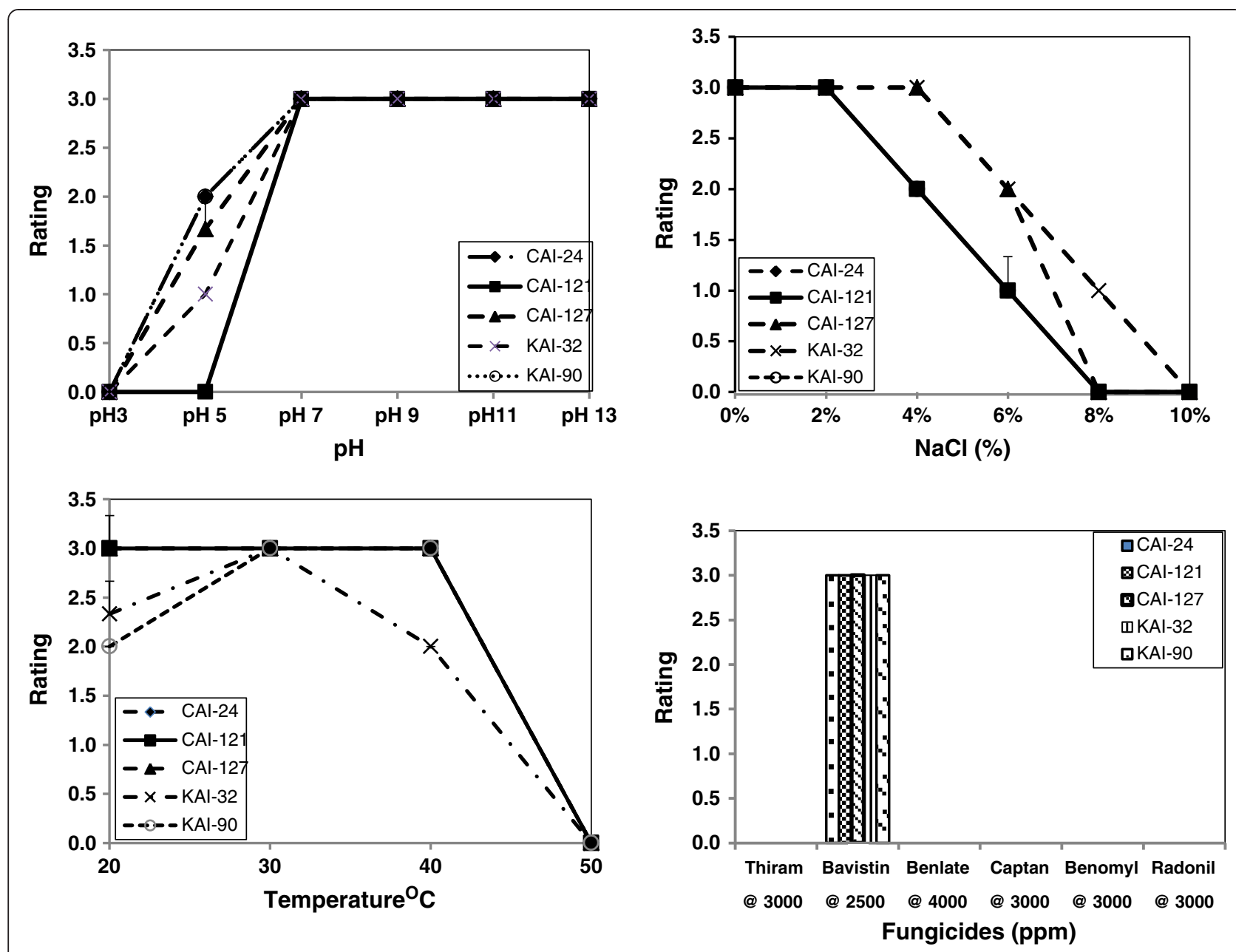

Figure 2 Evaluation of the five Streptomyces strains antagonistic to FOC for their tolerance of salinity, $\mathrm{pH}$, temperature and fungicides (at field level application).

Evaluation of Streptomyces strains for their PGP potential on sorghum under greenhouse conditions

The Streptomyces strains significantly enhanced all PGP parameters; plant height (16 - 51\%), leaf area (11 - 24\%, except KAI-32), stem weight (7 - 39\%, except CAI-127), leaf weight $(2-12 \%)$, root length $(3-18 \%)$, root surface area $(2-11 \%$, except CAI-121), root volume (2 - 19\%) and root dry weight $(4-25 \%)$ over the control (Table 1$)$.

\section{Evaluation of Streptomyces strains for their PGP potential} under field conditions on rice

Under field conditions in rice, the five Streptomyces strains significantly enhanced plant height $\left(\mathrm{cm}\right.$ plant $\left.{ }^{-1}\right)$, tillers $\left(\mathrm{m}^{-2}, 9-28 \%\right)$, primary and secondary panicle number $\left(\right.$ plant $\left.^{-1}\right)$, panicle length $(\mathrm{cm})$, stover and grain yield ( $\mathrm{g} \mathrm{m}^{-2}, 6-25 \%$ and $0.2-10 \%$, respectively), total dry matter $\left(\mathrm{g} \mathrm{m}^{-2}, 3-18 \%\right)$ and test seed weight (g) over the control (Table 2). Root length $\left(\mathrm{mm}^{-2}, 3-15 \%\right)$, root volume $\left(\mathrm{cm}^{-3} \mathrm{~m}^{-2}, 1-35 \%\right)$ and root dry weight $\left(\mathrm{gm}^{-2}\right.$, $2-55 \%)$ were also found significantly enhanced in both the soil depths $(0-15 \mathrm{~cm}$ and $15-30 \mathrm{~cm})$ in all the Streptomyces strains (except CAI-24) inoculated plots over the control (Table 3). The soil biological activities (microbial biomass carbon [ $\mu \mathrm{g} \mathrm{g}^{-1}$ soil, $0.5-41 \%$ ], microbial biomass nitrogen [ $\mu \mathrm{g} \mathrm{g}^{-1}$ soil, $7-52 \%$ ] and dehydrogenase activity [ $\mu \mathrm{g}$ TPF g ${ }^{-1}$ soil $24 \mathrm{~h}^{-1}, 2-75 \%$ ]) in the top $15 \mathrm{~cm}$ rhizosphere soils were significantly higher in Streptomyces inoculated treatments (except CAI-24) at harvest, over the control (Table 4). The total N, available P and organic carbon\% (chemical activities) were also found significantly enhanced in the top $15 \mathrm{~cm}$ of rhizosphere soils of Streptomyces treated plants (by $67-122 \%, 32-53 \%$ and $0-$ $13 \%$, respectively) at harvesting than those of the controls (Table 4).

\section{Discussion}

The five Streptomyces strains (CAI-24, CAI-121, CAI127, KAI-32 and KAI-90) used in the present investigation were earlier reported as not only having potential for biocontrol of Fusarium wilt disease in chickpea but 
Table 1 Evaluation of the five Streptomyces strains antagonistic to FOC for their plant growth promotion potential in sorghum under greenhouse conditions

\begin{tabular}{|c|c|c|c|c|c|c|c|c|}
\hline Treatment & $\begin{array}{c}\text { Plant } \\
\text { height } \\
(\mathrm{cm})\end{array}$ & $\begin{array}{l}\text { Leaf } \\
\text { area } \\
\left(\mathrm{cm}^{2}\right)\end{array}$ & $\begin{array}{c}\text { Stem } \\
\text { weight } \\
\text { (g) }\end{array}$ & $\begin{array}{l}\text { Leaf } \\
\text { weight } \\
\text { (g) }\end{array}$ & $\begin{array}{c}\text { Root } \\
\text { length } \\
\left(\mathrm{m}^{-1} \text { plant }^{-1}\right)\end{array}$ & $\begin{array}{c}\text { Surface } \\
\text { area } \\
\left(\mathrm{cm}^{2} \text { plant }^{-1}\right)\end{array}$ & $\begin{array}{c}\text { Root } \\
\text { volume } \\
\left(\mathrm{cm}^{3} \text { plant }^{-1}\right)\end{array}$ & $\begin{array}{c}\text { Root dry } \\
\text { weight } \\
\text { (g plant }^{-1} \text { ) }\end{array}$ \\
\hline CAl-24 & 114 & 560 & 5.42 & 2.28 & 90 & 1003 & 10.2 & 0.92 \\
\hline CAI-121 & 122 & 580 & 5.55 & 2.32 & 80 & 905 & 9.0 & 0.84 \\
\hline CAI-127 & 100 & 624 & 5.09 & 2.35 & 88 & 922 & 9.3 & 0.87 \\
\hline KAl-32 & 124 & 507 & 6.39 & 2.21 & 82 & 991 & 10.5 & 0.89 \\
\hline KAI-90 & 130 & 589 & 7.03 & 2.41 & 78 & 973 & 10.5 & 1.01 \\
\hline Control & 86 & 504 & 5.06 & 2.16 & 76 & 903 & 8.8 & 0.81 \\
\hline Mean & 113 & 561 & 5.76 & 2.29 & 82 & 949 & 9.7 & 0.89 \\
\hline SE \pm & $4.9^{* * *}$ & $27.5^{*}$ & $0.471^{*}$ & $0.048^{*}$ & $3.4^{*}$ & $13.9^{* * *}$ & $0.42^{*}$ & $0.036^{*}$ \\
\hline LSD (5\%) & 14.9 & 83.0 & 1.421 & 0.146 & 10.0 & 42.0 & 1.28 & 0.109 \\
\hline CV\% & 9 & 10 & 16 & 4 & 8 & 3 & 9 & 8 \\
\hline
\end{tabular}

$\mathrm{SE}=$ standard error; $\mathrm{LSD}=$ least significant difference; $C V=$ coefficient of variance; ${ }^{*}=$ statistically significant at $p=0.05 ;{ }^{* * *}=$ statistically significant at $p=0.001$.

also having PGP traits such as IAA (except KAI-90) and siderophore production (Gopalakrishnan et al. 2011b). Microbes producing IAA stimulate plant growth while siderophore producers bind $\mathrm{Fe}^{3+}$ from the environment and make it available for plants and their growth (Patten and Glick 2002; Tokala et al. 2002; Hayat et al. 2010). In the present investigation, the five FOC antagonistic Streptomyces were further characterized for enzymatic activities, physiological traits and PGP potential on sorghum and rice under greenhouse and field conditions.

In the enzymatic activity studies, all the five strains produced $\beta-1,3$-glucanase and lipase but only CAI-24, KAI-32 and KAI-90 produced chitinase. The cell walls of plant pathogens contain $\beta-1,3$-glucan, chitin and lipid, which are essential for the pathogen for disease transmission and pathogenesis, and lysis of these by $\beta-1,3-$ glucanase/chitinase/lipase-producing microbe leads to leakage of cell contents and collapse of the pathogenic fungi (Singh et al. 1999; Lynd et al. 2002; Macagnan et al. 2008). Hence, microorganisms having these traits can be exploited for biological control of plant pathogens, which indirectly promotes the plants. In the physiological traits studies, the five Streptomyces strains were able to grow in $\mathrm{NaCl}$ up to $6 \%$ and at $\mathrm{pH}$ values between 5 and 13 and temperatures between 20 and $40^{\circ} \mathrm{C}$. The ability of Streptomyces spp. to grow in harsh $\mathrm{pH}$ and temperature and higher concentration of salinity is reported (Sadeghi et al. 2012). In the present study, all the Streptomyces strains were highly tolerant to the fungicide Bavistin at field application level. Therefore, it is concluded that these strains may not only have the capability to survive in harsh environments but are also compatible with the Bavistin and hence can be used in integrated disease management programs.

In the present study, under greenhouse conditions in sorghum and field conditions in rice, the Streptomyces

Table 2 Effect of FOC antagonistic Streptomyces on the morphology and yield potential of rice cultivation

\begin{tabular}{|c|c|c|c|c|c|c|c|c|c|}
\hline Treatment & $\begin{array}{l}\text { Plant } \\
\text { height } \\
\text { (cm) }\end{array}$ & $\begin{array}{c}\text { Tillers } \\
\text { number }\left(\mathrm{m}^{-2}\right)\end{array}$ & $\begin{array}{l}\text { Primary } \\
\text { panicles } \\
\text { number }\end{array}$ & $\begin{array}{c}\text { Secondary } \\
\text { panicles } \\
\text { number }\end{array}$ & $\begin{array}{l}\text { Panicle } \\
\text { length } \\
\text { (cm) }\end{array}$ & $\begin{array}{c}\text { Stover } \\
\text { yield }\left(\mathrm{g} \mathrm{m}^{-2}\right)\end{array}$ & $\begin{array}{c}\text { Grain } \\
\text { yield }\left(\mathrm{g} \mathrm{m}^{-2}\right)\end{array}$ & $\begin{array}{c}\text { Total } \\
\text { dry matter } \\
\left(\mathrm{g} \mathrm{m}^{-2}\right)\end{array}$ & $\begin{array}{c}\text { Test seed } \\
\text { weight }(g)\end{array}$ \\
\hline CAl-24 & 85 & 586 & 11.9 & 29.8 & 24.8 & 584 & 587 & 1170 & 18.9 \\
\hline CAI-121 & 81 & 506 & 11.8 & 26.5 & 24.5 & 637 & 583 & 1221 & 18.9 \\
\hline CAI-127 & 80 & 501 & 12.1 & 31.0 & 24.6 & 754 & 619 & 1373 & 18.6 \\
\hline KAI-32 & 82 & 532 & 12.2 & 28.3 & 25.0 & 754 & 640 & 1394 & 19.3 \\
\hline KAI-90 & 81 & 589 & 11.7 & 27.8 & 24.5 & 693 & 587 & 1279 & 18.9 \\
\hline Control & 80 & 459 & 11.4 & 25.0 & 24.4 & 601 & 582 & 1183 & 18.6 \\
\hline Mean & 81 & 529 & 11.8 & 28.0 & 24.6 & 671 & 600 & 1270 & 18.9 \\
\hline $\mathrm{SE} \pm$ & $0.68^{* * *}$ & $15.6^{* * *}$ & $0.06^{* *}$ & $0.29 * * *$ & $0.09^{*}$ & $27.8^{* *}$ & $9.7^{* *}$ & $31.9^{* * *}$ & $0.03^{* * *}$ \\
\hline LSD (5\%) & 2.0 & 47.1 & 0.22 & 1.06 & 0.33 & 87.7 & 30.5 & 100.4 & 0.11 \\
\hline CV\% & 2 & 7 & 1 & 2 & 1 & 7 & 3 & 4 & 1 \\
\hline
\end{tabular}

$\mathrm{SE}=$ standard error; $\mathrm{LSD}=$ least significant difference; $C V=$ coefficient of variance; ${ }^{*}=$ statistically significant at $p=0.05 ; * *=$ statistically significant at $p=0.01$; *** $=$ statistically significant at $\mathrm{p}=0.001$. 
Table 3 Effect of FOC antagonistic Streptomyces on the root development of rice at harvesting stage of rice cultivation

\begin{tabular}{|c|c|c|c|c|c|c|c|c|c|}
\hline \multirow[t]{2}{*}{ Treatment } & \multicolumn{3}{|c|}{ Root length $\left(\mathrm{m} \mathrm{m}^{-2}\right)$} & \multicolumn{3}{|c|}{ Root volume $\left(\mathrm{cm}^{-3} \mathrm{~m}^{-2}\right)$} & \multicolumn{3}{|c|}{ Root dry weight $\left(\mathrm{g} \mathrm{m}^{-2}\right)$} \\
\hline & $0-15 \mathrm{~cm}$ & $15-30 \mathrm{~cm}$ & Mean & $0-15 \mathrm{~cm}$ & $15-30 \mathrm{~cm}$ & Mean & $0-15 \mathrm{~cm}$ & $15-30 \mathrm{~cm}$ & Mean \\
\hline CAI-24 & 3798 & 375 & 2087 & 745 & 46 & 396 & 58.3 & 2.8 & 30.5 \\
\hline CAI-121 & 5859 & 667 & 3263 & 945 & 81 & 513 & 66.7 & 5.3 & 36.0 \\
\hline CAI-127 & 6348 & 591 & 3470 & 1303 & 81 & 692 & 93.5 & 5.4 & 49.5 \\
\hline KAI-32 & 6490 & 813 & 3652 & 1170 & 84 & 627 & 101.9 & 6.8 & 54.3 \\
\hline KAI-90 & 5865 & 1319 & 3592 & 1009 & 153 & 581 & 79.7 & 9.8 & 44.8 \\
\hline Control & 5776 & 588 & 3182 & 932 & 81 & 507 & 65.0 & 5.1 & 35.1 \\
\hline $\mathrm{SE} \pm$ & & $121.9(128.0)^{* * *}$ & $81.6^{* * *}$ & & $22.5(21.3)^{* * *}$ & $16.8^{* * *}$ & & $2.59(2.51)^{* * *}$ & $1.89^{* * *}$ \\
\hline Mean & 5689 & 726 & & 1017 & 88 & & 77.5 & 5.9 & \\
\hline $\mathrm{SE} \pm$ & & $52.3^{* * *}$ & & & $8.7^{* * *}$ & & & $1.02^{* * *}$ & \\
\hline CV\% & & 7 & & & 7 & & & 10 & \\
\hline
\end{tabular}

$\mathrm{SE}=$ standard error; $\mathrm{CV}=$ coefficient of variance; ${ }^{* * *}=$ statistically significant at $\mathrm{p}=0.001$.

strains significantly enhanced all the agronomic observations including root length, volume and dry weight and yield parameters over the un-inoculated control. The Streptomyces strains are reported widely in the literature for its PGP potential (Nassar et al. 2003; El-Tarabily 2008; Gopalakrishnan et al. 2012a; 2013b). As hypothesized earlier, the mechanism by which the Streptomyces enhanced the morphological and yield parameters on both sorghum and rice could be their PGP traits including IAA and siderophore production (direct stimulation of PGP; Gopalakrishnan et al. 2011b) and or chitinase, lipase and $\beta-1,3$-glucanase production (indirect stimulation of PGP; as reported in the present investigation). The effect of soil microbes on PGP including root development has been reported by Birkhofer et al. (2008) and Uphoff et al. (2009).

In the SRI method of rice cultivation, irrigation was done by alternate wetting and drying method. Such a system of irrigation favors soil microbial and biological activities and enhances the availability of mineral nutrients compared to rice grown by flooded cultivation methods (Uphoff et al. 2009; Gopalakrishnan et al. $2012 b)$. In the present investigation, soil biological activities including microbial biomass carbon, nitrogen and dehydrogenase and mineral nutrients including available $\mathrm{P}$, total $\mathrm{N}$ and \% organic carbon were found to be higher in the five Streptomyces inoculated plots over the uninoculated control plots. Similar results were found in SRI rhizospheres compared with those of the same variety of rice plants grown conventionally (Gayathry 2002). Hence, it can be concluded that the five Streptomyces strains survived in the rice rhizosphere and enhanced the soil health conditions. In the present investigation, although roots were not checked for colonization, the data on agronomical (including roots), yield, biological and mineral nutrition studies indicate that the five

Table 4 Effect of FOC antagonistic Streptomyces on soil biological activities and mineral nutrients at harvesting stage of rice cultivation

\begin{tabular}{|c|c|c|c|c|c|c|}
\hline Treatment & $\begin{array}{r}\text { Microbial } \\
\text { biomass C } \\
\left(\mu \mathrm{g} \mathrm{g}^{-1} \text { soil) }\right. \\
\end{array}$ & $\begin{array}{r}\text { Microbial } \\
\text { biomass } \mathrm{N} \\
\left(\mu \mathrm{g} \mathrm{g}^{-1} \text { soil) }\right. \\
\end{array}$ & $\begin{array}{c}\text { Dehydrogenase } \\
\text { activity } \\
\left(\mu \mathrm{g} \mathrm{TPF} \mathrm{g}^{-1} \text { soil } 24 \mathrm{~h}^{-1}\right)\end{array}$ & $\begin{array}{c}\text { Total } \mathrm{N} \\
\text { (g kg }{ }^{-1} \text { soil) }\end{array}$ & $\begin{array}{l}\text { Available } P \\
\text { (mg g } \\
\text { (-1 soil) }\end{array}$ & $\begin{array}{c}\text { Organic } \\
\text { carbon (\%) }\end{array}$ \\
\hline CAI-24 & 1715 & 60 & 94 & 2.456 & 0.133 & 1.49 \\
\hline CAI-121 & 3293 & 65 & 113 & 1.992 & 0.117 & 1.47 \\
\hline CAI-127 & 2875 & 88 & 194 & 2.644 & 0.115 & 1.52 \\
\hline KAI-32 & 4020 & 65 & 135 & 2.142 & 0.122 & 1.66 \\
\hline KAI-90 & 2946 & 62 & 136 & 2.160 & 0.129 & 1.62 \\
\hline Control & 2861 & 58 & 111 & 1.190 & 0.087 & 1.47 \\
\hline Mean & 2952 & 66 & 131 & 2.231 & 0.117 & 1.53 \\
\hline $\mathrm{SE} \pm$ & $150.5^{* * *}$ & $3.7^{* *}$ & $9.3^{* * *}$ & $0.063^{*}$ & $0.005^{*}$ & $0,032^{*}$ \\
\hline LSD (5\%) & 520.7 & 12.0 & 29.7 & 0.229 & 0.019 & 0.116 \\
\hline CV\% & 9 & 10 & 12 & 4 & 6 & 3 \\
\hline
\end{tabular}

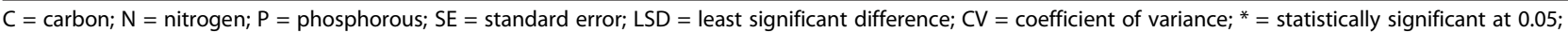
$*^{* *}=$ statistically significant at $\mathrm{p}=0.01 ;{ }^{* * *}=$ statistically significant at $\mathrm{p}=0.001$. 
Streptomyces strains had multiplied and colonized the rice roots. Hence, it can be concluded that the five Streptomyces strains used in this study were apparently well adapted to the rice and sorghum rhizosphere environments and enhanced the soil health and plant growth conditions. Significant increases in growth and yield of agronomically important crops in response to inoculation with PGP microbes have been repeatedly reported (Biswas et al. 2000; Asghar et al. 2002; Silva et al. 2006). PGP microbes are thought to stimulate plant growth by two mechanisms: (1) by altering hormone balance in the host plant and increasing mineral nutrient solubilization (direct effects); (2) by antagonism towards plant pathogens (indirect effects; Glick 1995). In the present investigation, the five Streptomyces strains were found to have both mechanisms, having PGP traits in rice and sorghum (direct effects) and biocontrol traits, against Fusarium wilt, in chickpea (indirect effects; Gopalakrishnan et al. 2011b). Broad spectrum PGP and biocontrol agents offer potentially effective novel strategies for controlling multiple pathogens and insect pests. A few of the available biocontrol agents, mostly belonging to Pseudomonas spp., have shown broad spectrum antifungal activity (Hass and Keel 2003; Viji et al. 2003; Kishore et al. 2005). Actinomycetes and other bacteria are also reported in the literature as broad spectrum PGP and biocontrol agents for soilborne fungal plant pathogens and insect-pests, such as Helicoverpa armigera and Spodoptera litura (El-Tarabily and Sivasithamparam 2006; Sadeghi et al. 2012).

The five Streptomyces used in this study were well adapted to not only in the chickpea rhizosphere but also in the sorghum and rice rhizosphere where they promoted plant growth. Hence, these isolates could be used as PGP agents in addition to the biocontrol of Fusarium wilt. Though, all the five strains have been demonstrated for their PGP potential in rice KAI-32 and KAI-90 were found to have superiority over other isolates in terms of crop productivity and root development. The broad range of PGP and antifungal activities of the five Streptomyces strains demonstrates multiple mechanisms of actions including antibiosis, production of cell wall degrading enzymes and plant growth-promoting hormone (IAA). Therefore, these Streptomyces can be considered for isolation of novel secondary metabolites which may be of importance for various biocontrol and PGP applications. Use of biocontrol agents such as these broadspectrum Streptomyces will probably be one of the important tactics for plant disease management in the near future as they allow the reduced use of pesticides and fertilizers that are potential pollutants of the environment.

\section{Competing interests}

The authors declare that they have no competing interests.

\section{Authors' contributions}

SG, VS and MSV carried out the in vitro and field studies, AR done the statistical analysis and SG drafted the manuscript. All authors read and approved the final manuscript.

\section{Acknowledgements}

We thank the National Bureau of Agriculturally Important Microorganisms for providing financial support. We also thank all the staff of the biocontrol unit of ICRISAT including M/s PVS Prasad, P Manohar, B Nagappa, D Barath, A Jabbar and $S$ Rohini for their significant inputs in the laboratory, greenhouse and field studies.

Received: 12 September 2013 Accepted: 21 October 2013

Published: 29 October 2013

\section{References}

Anderson TH, Domsch KH (1989) Ratios of microbial biomass carbon to total organic carbon in arable soils. Soil Biol Biochem 21:471-479

Asghar HN, Zahir ZA, Arshad M, Khalig A (2002) Plant growth regulating substances in the rhizosphere: microbial production and functions. Adv Agron 62:146-151

Basak BB, Biswas DR (2009) Influence of potassium solubilizing microorganisms (Bacillus mucilaginosus) and waste mica on potassium uptake dynamics by sudan grass (Sorghum vulgare Pers.) grown under tow Alfisols. Plant Soil 317:235-255

Bhattacharya A, Chandra S, Barik S (2009) Lipase and protease producing microbes from the environment of sugar beet field. Ind J Agric Biochem 22:26-30

Birkhofer K, Bezemer TM, Bloem J, Bonokowski M, Chritensen S, Dubois D, Ekelund F, Fliessbach A, Gunst L, Hedlund K, Mader P, Mikola J, Robin C, Setala H, Tatin-Froux F, Van der Putten W, Scheu S (2008) Long-term organic farming fosters below and above ground biota; implications for soil quality, biological control and productivity. Soil Biol Biochem 40:2297-2308

Biswas JC, Ladha JK, Dazzo FB (2000) Rhizobial inoculation influences seedling vigor and yield in rice. Agrono J 92:880-886

Borriss R, Chen XH, Rueckert C, Blom J, Becker A, Baumgarth B, Fan B, Pukall R, Schumann P, Sproer C, Junge H, Vater J, Puhler A, Klenk HP (2011) Relationship of Bacillus amyloliquefaciens clades associated with strains DSM7T and FZB42T: a proposal for Bacillus amyloliquefaciens subsp. amyloliquefaciens subsp. nov. and Bacillus amyloliquefaciens subsp. plantarum subsp. nov. based on complete genome sequence comparisons. Int J Syst Evol Microbiol 61:1786-1801

Brooks PC, Landman A, Pruden G, Jenkinson DS (1985) Chloroform fumigation and the release of soil nitrogen; a rapid direct extraction method to measure microbial biomass nitrogen in soil. Soil Biol Biochem 17:837-842

Casida LE (1977) Microbial metabolic activity in soil as measured by dehydrogenase determinations. Appl Environ Microbiol 34:630-636

El-Tarabily KA (2008) Promotion of tomato (Lycopersicon esculentun Mill.) plant growth by rhizosphere competent 1-aminocyclopropane-1-carboxylic acid deaminase-producing Streptomycete actinomycetes. Plant Soil 308:161-174

El-Tarabily KA, Sivasithamparam K (2006) Non-streptomycete actinomycetes as biocontrol agents of soil-borne fungal plant pathogens and as plant growth promoters. Soil Biol Biochem 38:1505-1520

Gayathry G (2002) Studies on dynamics of soil microbes in rice rhizosphere with water saving irrigation and in-situ weed incorporation, Ph.D. Thesis submitted to Tamil Nadu. Agricultural University, Coimbatore, India

Glick BR (1995) The enhancement of plant-growth by free-living bacteria. Can J Microbiol 41:109-117

Gopalakrishnan S, Humayun P, Kiran BK, Kannan IGK, Vidya MS, Deepthi K, Rupela $\mathrm{O}$ (2011a) Evaluation of bacteria isolated from rice rhizosphere for biological control of charcoal rot of sorghum caused by Macrophomina phaseolina (Tassi) Goid. World J Microbiol Biotechnol 27:1313-1321

Gopalakrishnan S, Pande S, Sharma M, Humayun P, Kiran BK, Sandeep D, Vidya MS, Deepthi K, Rupela O (2011b) Evaluation of actinomycete isolates obtained from herbal vermicompost for biological control of Fusarium wilt of chickpea. Crop Protect 30:1070-1078

Gopalakrishnan S, Humayun P, Srinivas V, Vijayabharathi R, Ratnakumari B, Rupela O (2012a) Plant growth-promoting traits of Streptomyces with biocontrol potential isolated from herbal vermicompost. Biocontrol Sci Technol 22:1110-1199 
Gopalakrishnan S, Upadhyaya HD, Vadlamudi S, Humayun P, Vidya MS, Alekhya G, Singh A, Vijayabharathi R, Bhimineni RK, Seema M, Rathore A, Rupela O (2012b) Plant growth-promoting traits of biocontrol potential bacteria isolated from rice rhizosphere. Springer Plus 1:71

Gopalakrishnan S, Kumar RM, Humayun P, Srinivas V, Ratnakumari B, Vijayabharathi R, Singh A, Surekha K, Padmavathi C, Somashekar N, Rao RP, Rao LVS, Babu VR, Viraktamath BC, Goud W, Loganandhan N, Gujja B, Rupela O (2013a) Assessment of different methods of rice (Oryza sativa, L) cultivation for growth parameters, soil chemical, biological and microbiological properties, water saving and grain yield in rice-rice system. Paddy Water Environ, doi:10.1007/s10333-013-0362-6

Gopalakrishnan S, Srinivas V, Shravya A, Prakash B, Vijayabharathi R, Ratna Kumari B, Rupela O (2013b) Evaluation of Streptomyces spp. for their plant-growthpromotion traits in rice. Can J Microbiol 50:534-539

Hao D, Gao P, Liu P, Zhao J, Wang Y, Yang W, Lu Y, Shi T, Zhang X (2011) AC3-33, a novel secretory protein, inhibits Elk1 transcriptional activity via ERK pathway. Mol Biol Rep 38:1375-1382

Hass D, Keel C (2003) Regulation of antibiotic production in root-colonized Pseudomonas spp. and relevance for biological control of plant disease. Ann Rev Phytopathol 41:117-153

Hayat R, Ali S, Amara U, Khalid R, Ahmed I (2010) Soil beneficial bacteria and their role in plant growth promotion: a review. Ann Microbiol 60:579-598

Hirano S, Nagao N (1988) An improved method for the preparation of colloidal chitin by using methanesulfonic acid. Agric Biol Chem 52:2111-2112

Khan MR, Khan SM, Mohiddin FA (2004) Biological control of Fusarium wilt of chickpea through seed treatment with the commercial formulation of Trichoderma harzianum and/or Pseudomonas fluorescens. Phytopathol Mediterr 43:20-25

Kishore GK, Pande S, Podile AR (2005) Biological control of collar rot disease with broad spectrum antifungal bacteria associated with groundnut. Can J Microbiol 51:122-132

Kloepper JW (2009) Plant growth-promotion by rhizobacteria for sustainable agriculture, Proceedings of first Asian PGPR congress held between 21st and 24th June at Acharya N.G. Ranga Agricultural University, Rajendranagar, Hyderabad, India

Lynd LR, Weimer PJ, Van ZWH, Pretorius IS (2002) Microbial cellulose utilization: fundamentals and biotechnology. Microbiol Mol Biol Rev 66:506-577

Macagnan D, Romeiro RDA, Pomella AMV, deSouza JT (2008) Production of lytic enzymes and siderophores, and inhibition of germination of basidiospores of Moniliophthora (ex Crinipellis) perniciosa by phylloplane actinomycetes. Biol Control 47:309-314

Nassar AH, El-Tarabily KA, Sivasithamparam K (2003) Growth promotion of bean (Phaseolus vulgaris L.) by a polyamine producing isolate of Streptomyces griseoluteus. Plant Growth Reg 40:97-106

Nelson DW, Sommers LE (1982) Total organic carbon and organic matter. In: Page AL, Miller RH, Keeney DR (eds) Methods of soil analysis; Part 3, Chemical and microbiological properties. SSSA, Madison, WI, pp 539-579

Novozamsky I, Houba VJG, Van ECKR, vanVark W (1983) A novel digestion technique for multiple element analysis. Commun Soil Sci Plant Anal 14:239-249

Olsen SR, Sommers LE (1982) Phosphorus. In: Page AL (ed) Methods of soil analysis, Agronomy No. 9, Part 2, chemical and microbial properties, 2nd edition. American Society of Agronomy, Madison, WI, USA, pp 403-430

Panhwar QA, Othman R, Rahman ZA, Meon S, Ismail MR (2012) Isolation and characterization of phosphate-solubilizing bacteria from aerobic rice. Afr J Biotechnol 11:2711-2719

Patten C, Glick BR (2002) Role of Pseudomonas putida in indole acetic acid in development of the host plant root system. Appl Environ Microbiol 68:3795-3801

Perner H, Schwarz D, George E (2006) Effect of mycorrhizal inoculation and compost supply on growth and nutrient uptake of young leek plants grown on peat-based substrates. Hort Sci 41:628-632

Postma J, Montanari M, Van den Boogert PHJF (2003) Microbial enrichment to enhance disease suppressive activity of compost. Euro J Soil Biol 39:157-163

Sadeghi A, Karimi E, Dahazi PA, Javid MG, Dalvand Y, Askari H (2012) Plant growth promoting activity of an auxin and siderophore producing isolate of Streptomyces under saline soil condition. World J Microbiol Biotechnol 28:1503-1509

Silva VN, Silva LESF, Figueiredo MVB (2006) Atuac,ão de rizo'bios com izobacté rias promotora de crescimento em plantas na cultura do caupi (Vigna unguiculata L. Walp). Acta Scientiarum Agron 28:407-412
Singh PP, Shin YC, Park CS, Chung YR (1999) Biological control of Fusarium wilt of cucumber by chitinolytic bacteria. Phytopathology 89:92-99

Tinatin D, Nurzat T (2006) Biodiversity of Streptomyces of high-mountainous ecosystems of Kyrgystan and its biotechnological potential. Antonie Leeuwenhoek 89:325-328

Tokala RK, Strap JL, Jung CM, Crawford DL, Salove MH, Deobald LA, Bailey JF, Morra MJ (2002) Novel plant-microbe rhizosphere interaction involving Streptomyces lydicus WYEC108 and the pea plant (Pisum sativum). Appl Environ Microbiol 68:2161-2171

Torsvik V, Ovreas L, Thingstad TF (2002) Prokaryotic diversity: magnitude, dynamics and controlling factors. Science 296:1064-1066

Uphoff N (2003) Higher yields with fewer external inputs? The system of rice intensification and potential contributions to agricultural sustainability. Int J Agric Sustain 1:38-50

Uphoff N, Anas I, Rupela OP, Thakur AK, Thyagarajan TM (2009) Learning about positive plant-microbial interactions from the system of rice intensification (SRI). Aspect Appl Biol 98:29-54

Viji G, Uddin W, Romaine CP (2003) Suppression of gray leaf spot (blast) of perennial ryegrass turf by Pseudomonas aeruginosa from spent mushroom substrate. Biol Control 26:379-407

\section{doi:10.1186/2193-1801-2-574}

Cite this article as: Gopalakrishnan et al.: Plant growth-promoting activities of Streptomyces spp. in sorghum and rice. SpringerPlus 2013 2:574.

\section{Submit your manuscript to a SpringerOpen ${ }^{\circ}$ journal and benefit from:}

- Convenient online submission

- Rigorous peer review

- Immediate publication on acceptance

- Open access: articles freely available online

- High visibility within the field

- Retaining the copyright to your article

Submit your next manuscript at springeropen.com 